\title{
Is Switzerland an Interest Rate Island after all? Time Series and Non-Linear Switching Regime Evidence
}

\author{
Lars P. Feld \\ Ekkehard A. Köhler
}

CESIFO WORKING PAPER NO. 5628

CATEGORY 7: MONETARY POLICY AND INTERNATIONAL FinANCE

NOVEMBER 2015

An electronic version of the paper may be downloaded

- from the SSRN website:

- from the RePEc website:

wWw.SSRN.com

- from the CESifo website:

Www.RePEc.org

www.CESifo-group.org/wp 


\title{
Is Switzerland an Interest Rate Island after all? Time Series and Non-Linear Switching Regime Evidence
}

\begin{abstract}
Has the "Swiss interest rate anomaly" persisted after the financial crisis? Regarding the hypothesis that the Swiss interest rate anomaly results from systemic risk anticipation, we discuss whether Switzerland remains an interest rate island in the wake of the financial crisis. We find evidence for the demise of the interest rate bonus of the Swiss franc (CHF) vis-à-vis the Euro (EUR) after the Swiss National Bank (SNB) started to advocate an exchange rate floor with the Euro. After the compression of the bonus to insignificant levels, the uncovered interest parity (UIRP) holds again. We find evidence for a recent regime switch after the SNB has discontinued the exchange rate floor with the Euro.
\end{abstract}

JEL-Codes: E420, E430, F430, G150.

Keywords: uncovered interest rate parity (UIRP), Swiss interest rate anomaly, error correction, heteroscedasticity, Markov regime switching.

Lars P. Feld

Walter Eucken Institute \& Albert-Ludwigs-University Freiburg

Goethestrasse 10

Germany - 79100 Freiburg

feld@eucken.de
Ekkehard A. Köhler

Walter Eucken Institute \&

Albert-Ludwigs-University Freiburg

Goethestrasse 10

Germany - 79100 Freiburg

koehler@eucken.de 


\section{Introduction}

The 70-year-long phenomenon of significantly lower mean returns on Swiss assets compared to other major currencies has been dubbed the "interest rate anomaly" or "interest rate puzzle", characterizing Switzerland as an "interest rate island" (Mishkin 1984, Cunat 2003, Dreger and Schumacher 2003, Kirchgässner 2003, Kugler and Weder 2002, 2005, 2009). One hypothesis to explain this phenomenon is that investors accept lower fixed income returns in the expectation of a future appreciation of the Swiss franc (CHF) after large-scale events such as a crisis or a war (Kugler and Weder 2004).

This safe haven explanation is most interesting to discuss for the following reasons: first, the financial and sovereign debt crisis can unquestionably be considered as a large-scale event. Second, a strong appreciation of the CHF in the wake of the crisis events suggests an empirical analysis of this "safe haven" explanation. Third, both developments have had important repercussions for Swiss monetary policy: the strong appreciation has given rise to "appreciation containment" actions by the Swiss National Bank that culminated in the introduction of an exchange rate floor with the Euro (EUR) in September 2011 that was discontinued in January 2015 (Studer and Jordan 2015).

Ex-post and after the SNB's decision, we are interested in testing whether the interest rate bonus persists (Baltensperger 2012: 226) or whether it has disappeared, as studies during the early phase of the Global Recession suggested (Kugler and Weder 2009, Hoffmann and Suter 2010). In particular, we investigate whether appreciation has eliminated the interest rate bonus and whether the SNB's reaction has had a significant effect on the interest rate anomaly. If the interest rate bonus persists or reappears, we have evidence that the CHF remains a safe haven - in anticipation of the next crisis.

The paper is organized as follows: we review the literature on this topic in section 2 followed by the theoretical framework in section 3 . In section 4 , we present the econometric modeling of the time series analysis. Section 5 summarizes the empirical results, Section 6 concludes.

\section{Literature Review}

The phenomenon of much lower returns on assets denominated in Swiss francs compared to assets of other major currencies has been described as the "interest rate anomaly" or "interest rate puzzle", respectively. This failure of the uncovered interest rate parity (UIRP) was discovered by Mishkin (1984). Early empirical studies on the Swiss interest rate anomaly were 
provided by Kirchgässner and Wolters $(1987,1991)$. Follow-up studies found a vanishing interest rate bonus at the end of the 1980s when market expectations were formed that Switzerland might join the European Economic Area (EEA) (Kirchgässner and Wolters 1993, 1995). Box 1 summarizes the major findings of recent studies on the Swiss interest rate anomaly since 2000. During the 1990s, the bonus emerged again in the wake of the referendum on December 6, 1992, when Swiss citizens rejected the proposition of joining the EEA by $50.3 \%$ of the votes cast (Kirchgässner 2003). Neither the introduction of the Euro in 1999 nor the September 11 event in 2001 diminished the bonus (Kirchgässner 2003). Kugler and Weder (2004) reported similar findings, but also found a persistent negative excess return of the CHF against the Euro (EUR) and US-Dollar (USD) denominated assets. They however predicted that the puzzle would disappear once bad times hit the market and the CHF appreciated.

Box 1 Studies on the Swiss Interest Rate Anomaly since 2000

\begin{tabular}{|c|c|c|c|c|}
\hline & Time period & CHF vs. & Econometrics & Key findings \\
\hline $\begin{array}{l}\text { Kirchgässner } \\
(2003)\end{array}$ & $01.1981-02.2003$ & EUR USD & VECM & $\begin{array}{l}\text { Bonus reappears after referendum. Long-term } \\
\text { bonus } 1 \text { percent vs. EUR, } 2 \text { percent vs. USD. }\end{array}$ \\
\hline $\begin{array}{l}\text { Kugler and } \\
\text { Weder }(2004)\end{array}$ & $1980-2003$ & EUR USD & OLS & $\begin{array}{l}\text { Persistent negative excess returns of CHF vs. } \\
\text { USD and EUR. }\end{array}$ \\
\hline $\begin{array}{l}\text { Kugler and } \\
\text { Weder (2009) }\end{array}$ & $\begin{array}{l}\text { 1980-1998 } \\
\text { compared to } \\
1999-2008\end{array}$ & EUR USD & OLS & $\begin{array}{l}1999-2008 \text { interest anomaly is reduced } \\
\text { compared to } 1980-1998 .\end{array}$ \\
\hline $\begin{array}{l}\text { Hoffmann and } \\
\text { Suter (2010) }\end{array}$ & 01.1990-04.2009 & $\begin{array}{l}\text { CAD EUR } \\
\text { GBP JPY USD }\end{array}$ & OLS & $\begin{array}{l}\text { Safe haven behavior is latent. } \\
\text { Significant impact of crises events. }\end{array}$ \\
\hline $\begin{array}{l}\text { Krishnakumar } \\
\text { and Neto } \\
(2012)\end{array}$ & 01.1993-10.2008 & EUR USD & $\begin{array}{l}\text { Threshold } \\
\text { VECM }\end{array}$ & $\begin{array}{l}\text { UIRP holds (CHF and DEM/EUR) } \\
\text { UIRP does not hold for CHF and USD }\end{array}$ \\
\hline $\begin{array}{l}\text { Mollick and } \\
\text { Assefa (2013) }\end{array}$ & 01.1986-10.2009 & EUR USD & $\begin{array}{l}\text { Panel analysis } \\
\text { (Multivariate) }\end{array}$ & $\begin{array}{l}-2.22 \text { percent against USD; UIRP does not } \\
\text { hold. } \\
\text { Strong appreciation after market turmoil events. }\end{array}$ \\
\hline $\begin{array}{l}\text { Grisse and } \\
\text { Nitschka } \\
(2015)\end{array}$ & 01.1990-08.2011 & $\begin{array}{l}\text { AUD CAD } \\
\text { EUR JPY NZD } \\
\text { NOK SGD ZAR } \\
\text { SEK GBP USD }\end{array}$ & OLS & $\begin{array}{l}\text { Safe haven characteristics of CHF against } \\
\text { typical funding currencies in currency carry } \\
\text { trades (EUR, ZAR, AUD, NZD) } \\
\text { Appreciation if VIX increases (EUR) }\end{array}$ \\
\hline
\end{tabular}

*Currency codes in accordance with ISO 4217

In line with this „safe haven“ explanation, Kugler and Weder (2009) expected "the demise of the interest rates bonus" at the beginning of the financial crisis. They compared the periods of 1980 to 1998 with 1999 to 2008 and found a reduced interest rate bonus in the second period. Their prediction was confirmed by a study that incorporated data from the early stage of the crisis: Hoffmann and Suter (2010) concluded that the interest anomaly had vanished during the crisis. "This may lead a researcher to conclude that the safe haven property of a given currency is no longer apparent or has vanished altogether", as they conclude. However, they argue that 
the bonus is latent despite the fact that crises-related events, such as the collapse of Lehman Brothers, had a significant impact on its reversal. Hence, the study confirmed the expected effect of a "large-scale event" as predicted by Kugler and Weder (2004). All of these studies, however, could not reject the hypothesis that the Swiss franc denominated assets carried an interest bonus over the main course of the time periods.

Post-crisis studies have adopted new econometric techniques for time series, such as threshold Vector Autoregressive (VAR) processes (Krishnakumar and Neto 2012) or panel time series econometrics (Mollick and Assefa 2013). Others have applied survey based evidence and deviated from the assumption of rational expectations (Grisse and Nitschka 2015). While Krishnakumar and Neto find that the UIRP holds for Deutsche Mark (DEM) and CHF rates, they reject it for USD and CHF rates. Mollick and Assefa support the latter findings and quantify the interest rate bonus of the CHF against the USD at 2.22 percent. Thus, evidence for a persistent interest rate bonus between EUR and CHF is less strong. This is supported by Grisse and Nitschka (2015) who show that the CHF appreciates against the EUR when global risks as measured in VIX returns have risen. In addition, they show that the UIRP holds ex-ante for most currency pairs under observation.

Summing up, three key issues are worth discussing: first, all studies report systematically lower mean returns of CHF denominated short-term assets during the 1990s and the period before the financial crisis. Second, most studies predict a demise of the interest rate bonus, although evidence is inconclusive. Third, the Swiss interest bonus varies across time.

In the following, we re-estimate the interest rate anomaly with recent data that influence the events of the financial crisis and the September 2011 event when the SNB counteracted the strong CHF appreciation. In addition, we include daily data as robustness checks to further discuss when the bonus disappeared. Finally, we estimate non-linear models to further explore time-varying characteristics of the UIRP.

\section{Theoretical Framework}

The parity of prices and interest rates between economies is expected to hold in the long run in the context of the theoretical concept of arbitrage as initially adopted to explain financial globalization in classical economics (Ricardo 1811, Walras 1874). Keynes (1923) presented a formalized approach to explain the interest rate parity. His concept adopted financial arbitrage as the driving force to equalize interest rate differences over a sufficiently long period of time. 
The modern theoretical background of the relation between international interest rates originates in the Uncovered Interest Rate Parity (UIRP) that expects foreign and domestic assets to be close substitutes. Considering bonds in two different countries denominated in different currencies, the difference between their nominal interest rates should be determined by the expected relative change in the associated exchange rate $\frac{E_{t}\left[S_{t+1}\right]-S_{t}}{S_{t}}$, as equation (1) indicates (see also Alvarez et al. 2007):

$$
i_{t}=i_{t}^{*}+\frac{E_{t}\left[S_{t+1}\right]-S_{t}}{S_{t}}
$$

Let $i_{\mathrm{t}}$ be the domestic interest rate and $i_{\mathrm{t}}{ }_{\mathrm{t}}$ the foreign one in period $t$, and $E_{t}$ the expectation operator in period $t$ of the $(\log )$ exchange rate $S_{t}$ in period $t+1$, then the forward difference operator $\Delta_{(t+1)}$ reduces the UIRP in eq. 1 to

$$
i_{\mathrm{t}}=i_{\mathrm{t}}^{*}+E_{\mathrm{t}}\left(\Delta_{(\mathrm{t}+1)}\right)
$$

Equation 2 builds on the theoretical concept of arbitrage and is supported by strong empirical evidence for the UIRP to hold with $E_{\mathrm{t}}\left(\Delta_{(\mathrm{t}+1)}\right)$ as the forward difference operator (Frenkel and Levich 1975, 1977; Taylor 1987, 1989). If short-term money market interest rates are considered over the long run, the nominal exchange rate is approximated by random walks so that the forward rate (and the rational expectation) is a random walk process (Meese and Rogoff 1983). More recently Cheung et al. (2005) found that the predicting errors of the exchange rate are not lower than from a naïve model that simply assumes no change in the exchange rate. Against this backdrop of empirical evidence, the UIRP can be further reduced to

$$
\begin{gathered}
i_{\mathrm{t}}=i^{*}, \\
\text { If } E_{\mathrm{t}}\left(\Delta e_{(\mathrm{t}+1)}\right)=0 .
\end{gathered}
$$

Equation 3 is a testable hypothesis of the UIRP. In order to apply the UIRP, the random walk hypothesis of the interest rate differential is to be tested first, as proposed by Rogoff and Stavrakeva (2008) as well as by Rossi (2013). Recent studies have found non-stationary interest rates (Engel and West 2005, Engel et al. 2008) and the stationary interest rate differential, i.e., $E_{\mathrm{t}}\left(\Delta e_{(\mathrm{t}+1)}\right)$, is $\mathrm{I}(0)$.

To sum up, we can only apply the UIRP framework if the interest rate differential $E_{\mathrm{t}}(\Delta(\mathrm{t}+1))$ is stationary. If we cannot reject the hypothesis of random walk, the expected change of the exchange rate must be zero. It follows that the short term interest rates should be equal if we 
focus on assets with the same maturity, such as $t(\Delta(t+1))=0$. Taken together, we actually apply a joint test of the uncovered interest parity and the rational expectations hypothesis under the assumption that $\mathrm{t}(\Delta(\mathrm{t}+1))=0$ is not rejected.

\section{Data and Empirical Approach}

The Swiss interest rate anomaly describes the persistence of the violation of the arbitrage condition of the UIRP. In contrast and as explained in equation (1) - (3), economic theory predicts that returns of short maturity securities (e.g. three-month fixed income assets) are not systematically different from each other. Thus, we will test whether equation (3) holds in the long-run with a dataset of 3 months Libor rates between 1989 and 2015. We will present the dataset in the next step and present the econometric modeling of this time series analysis thereafter.

\subsection{Data}

We have retrieved 3 months $(3 \mathrm{~m})$ Libor rates for CHF, EUR, USD and British pound sterling (GBP) from the Swiss National Bank. ${ }^{1}$ We have chosen these rates for three reasons: first, they cover a major share of economic and financial trade relations with Switzerland (BIS 2013). Second, we consider Switzerland as a small open economy and thus expect the interest rates of large surrounding economies to have a strong influence. Third, our selection is based on former empirical studies that have proven their significant influence on CHF Libor rates (e.g. Dreger and Schuhmacher 2003; Kirchgässner 2003; Hoffmann and Suter 2010).

Selecting 3m Libor CHF, USD, EUR and GBP rates also ensures that two of the UIRP assumptions are met: first, transaction costs can be neglected due to economies of scale and the volume of the Libor marketplace. ${ }^{2}$ Second, we consider the financial market to have become increasingly sophisticated during the observed time horizon, which allows us to assume a near perfectly substitutive relation. Finally, the Swiss National Bank's monetary policy targets $3 \mathrm{~m}$ Libor rates on the operational level (SNB 2007, p.12,14). The fixing of the target range is

\footnotetext{
${ }^{1}$ We would like to thank Mr. Josef Bächtinger of the statistical group at the SNB for his help and feedback w.r.t. several inquiries and related questions on the dataset. The dataset is available here: http://www.snb.ch/de/iabout/stat/statpub/statmon/stats/statmon

${ }^{2}$ As far as the British Bankers Association (BBA) selects the commercial banks by scale, reputation and expertise in Fixed Income and Money Market operations, we indirectly rest upon their selection criteria, of course. The standardized poll is reflected by the question: "At what rate could you borrow funds, where you to do so by asking for and then accepting inter-bank offers in a reasonable market size prior to 11 am?”
} 
published regularly. By rule, "this target range extends over one percentage point" whereas "the SNB generally aims to keep the Libor in the middle of the range" (SNB 2007 p. 14). The dataset is collected in monthly quotes. The starting point of our analysis (January 1989) is set by the first banking day on which the BBA offered $3 \mathrm{~m}$ Libor rates for any of the four currencies under consideration.

\subsection{Empirical Approach}

The analysis is structured in five consecutive steps. First, we check for stationarity of the interest rate differentials of CHF, EUR, USD and GBP 3m Libor rates from January 1989 to February 2015 with 1256 observations in total. If the time series of interest rate differentials is explained by its lagged values plus a stochastic (non-systematic) component with i.i.d. errors, we have evidence of stationarity of interest rate differentials, i.e., I(0). If differentials are stationary, we have evidence that we can directly test the reduced form of the UIRP of equation (3). Second, we perform tests of stationarity for the interest rates in order to explore the order of integration of the interest rate series. Third, we analyze whether the time series are cointegrated by applying the Johansen Test procedure. If the series are cointegrated, we select the lag length in accordance with a vector autoregression procedure (VAR) for each interest rate series. Fourth, we specify the model using causality and block-exogeneity tests and estimate the long-term relation in an error correction model if we have evidence for cointegration. By analyzing subsamples of the time series, we test whether the events of the financial crisis and the SNB announcement to target an exchange rate floor of 1.20 CHF/EUR have had any effect on the Swiss interest rate anomaly. Fifth, we explore regime switching of $\mathrm{CHF}$ systems to examine non-linear characteristics of the time series under investigation.

\section{Time-series evidence}

Before we specify the model, we discuss stationarity properties of the time series and the interest rate differential (section 5.1). Thereafter, we specify and set up 25 year interest rate models of four interest rates (section 5.2). In a four-dimensional model we can expect multiple cointegration relations. We check the number of cointegration relations in Johansen procedures under various assumptions. At last, we offer robustness checks with daily data (section 5.3).

\subsection{Time series Analysis and Model Specification}

Since we test UIRP under the assumption that $E \mathrm{t}(\Delta(\mathrm{t}+1))=0$ is not rejected, we test whether the difference between the domestic and the foreign interest rate is stationary. We present the 
Augmented Dickey Fuller (ADF), Philipps Perron (PP) and Kwiatkowski (KPSS) test estimates of the interest rate differentials in Table 1:

Table 1 Tests for Unit Roots (ADF; PP) and stationarity (KPSS) in the interest rate difference, 1989m1 -2015m2

\begin{tabular}{lllll}
\hline & & $\Delta e \mathrm{CHF} / \mathrm{EUR}$ & $\Delta e \mathrm{CHF} / \mathrm{USD}$ & $\Delta e \mathrm{CHF} / \mathrm{GBP}$ \\
\hline ADF & Level & $-3.195^{* *}$ & -2.095 & -2.493 \\
& $1^{\text {st }}$ differences & $-17.857^{* * *}$ & -10.732 & -14.028 \\
$\mathbf{P P}$ & Level & $-3.070^{* *}$ & -1.811 & -2.262 \\
& $1^{\text {st }}$ differences & $-18.466^{* * *}$ & $-15.064^{* * *}$ & $-14.833^{* * *}$ \\
\multirow{2}{*}{ KPSS } & Level & 0.116 & $0.164^{* *}$ & $0.133^{* *}$ \\
& $1^{\text {st }}$ differences & 0.015 & $0.142^{*}$ & $0.120^{*}$ \\
\hline
\end{tabular}

Note: The values are the estimated t-statistics. '***', '**' or $^{\prime * \prime}$ indicates that the corresponding null hypothesis of a unit root (KPSS null: stationarity) is rejected at the 1, 5, or 10 percent level, respectively.

The differential is stationary for CHF/EUR but not stationary for CHF/GBP and CHF/USD. This implies, first, that the UIRP can be directly tested only for CHF and EUR. Second, exchange rate expectations are not described by a random walk in the case of the CHF/USD and the CHF/GPB differential. Thus, we cannot test the UIRP directly over the 25 -year period. However, both USD and GBP might influence the system of EUR and CHF, as we will check in Section 5.2.

To start exploring their relation, we estimate Johansen tests to identify the cointegration rank of the system. To do so, we first explore stationarity properties of these series. We start with unit root tests of the interest rates by estimating ADF and PP tests, as presented in Table 2. The estimates do not allow for the rejection of the null hypothesis of unit roots in levels, but reject the null hypothesis in first differences at the $1 \%$ significance level. We thus conclude that the time series are integrated of order one (I(1)).

Table 2 Tests for Unit Roots and Stationarity, 1989m1 -2015m2

\begin{tabular}{llcccc}
\hline & & 3m CHF & 3m EUR & 3m GBP & 3m USD \\
\hline ADF & Level & -1.139 & -1.116 & -2.453 & -2.339 \\
& $1^{\text {st }}$ differences & $-15.159 * * *$ & $-9.514 * * *$ & $-6.102^{* * *}$ & $-13.875^{* * *}$ \\
PP & Level & -1.040 & -1.030 & -1.600 & -1.882 \\
& $1^{\text {st }}$ differences & $-15.078^{* * *}$ & $-18.777^{* * *}$ & $-13.199 * * *$ & $-15.029 * * *$ \\
\multirow{2}{*}{ KPSS } & Level & $0.142^{* * *}$ & $0.129 * * *$ & $0.154^{* *}$ & $0.241^{* * *}$ \\
& $1^{\text {st }}$ differences & 0.084 & 0.089 & 0.058 & 0.087 \\
\hline
\end{tabular}

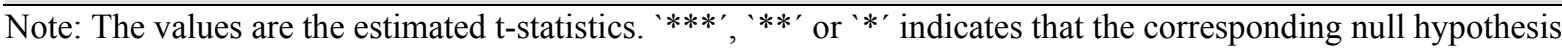
of a unit root (KPSS: null hypothesis of stationarity) is rejected at the 1, 5, or 10 percent level, respectively.

Since the variables are I(1), cointegration among them can be found. If the variables are cointegrated we can further explore their structural characteristics with a Vector Error Correction Model (VECM). The VECM separates the long-run from the short-run movements of the variables and allows to impose further restrictions on the long-run relation (Lütkepohl 
2005). The latter is of importance for our study since it allows for testing whether equation (3) holds in the long-run.

To specify the model, we continue with the Johansen procedure in order to determine the rank of the cointegration relation between CHF, EUR, GBP and USD. In such a four-dimensional system we can expect up to three cointegration relations. Thus, we will check for this possibility in the next step.

Selecting the lag length at 3 lags in a VAR in accordance with the Akaike- and Hannan-Quinn criterion and estimating five Johansen tests, we identify a minimum of one and a maximum of two cointegration relations (if we allow for a linear trend in the cointegration relation). Table 3 depicts the Trace and Max Eigenvalue test statistics for the different hypotheses (see note in Table 3), where $r$ is the number of cointegration relations (CIR). Consequently, we cannot reject the hypothesis that there is a long-run relation if we assume a linear trend in the data; however there might be more than one relation in the dataset.

Table 3: Johansen test results assuming a linear trend in the data

\begin{tabular}{|c|c|c|c|}
\hline \multicolumn{4}{|c|}{ Constant in CE } \\
\hline $\begin{array}{l}\text { Null } \\
\text { hypothesis }\end{array}$ & Eigenvalue & Trace statistic & $5 \%$ critical value \\
\hline None & 0.130 & $73.377 * * *$ & 47.856 \\
\hline At most1 & 0.049 & $29.990 *$ & 29.797 \\
\hline At most 2 & 0.026 & 14.242 & 15.495 \\
\hline \multirow[t]{2}{*}{ At most 3} & 0.019 & $5.941 * *$ & 3.841 \\
\hline & & \multicolumn{2}{|c|}{ Max. Eigenvalue statistic } \\
\hline 0 & 0.130 & $43.387 * * *$ & 27.584 \\
\hline 1 & 0.049 & 15.748 & 21.132 \\
\hline 2 & 0.026 & 8.300 & 14.264 \\
\hline 3 & 0.019 & $5.940 * *$ & 3.841 \\
\hline
\end{tabular}

\begin{tabular}{|c|c|c|c|}
\hline \multicolumn{4}{|c|}{ Constant and trend in CE } \\
\hline Null hypothesis & Eigenvalue & \multicolumn{2}{|c|}{ Trace statistic $5 \%$ critical value } \\
\hline None & 0.130 & $93.252 * * *$ & 63.876 \\
\hline At most1 & 0.087 & $49.915^{* * *}$ & 42.915 \\
\hline At most 2 & 0.045 & 25.872 & 25.872 \\
\hline \multirow[t]{2}{*}{ At most 3} & 0.022 & 12.518 & 12.518 \\
\hline & & \multicolumn{2}{|c|}{ Max. Eigenvalue statistic } \\
\hline 0 & 0.130 & $43.526^{* * *}$ & 32.118 \\
\hline 1 & 0.087 & $28.451 * *$ & 25.823 \\
\hline 2 & 0.045 & 14.337 & 19.387 \\
\hline 3 & 0.022 & 6.938 & 12.519 \\
\hline
\end{tabular}

Note: The Johansen test examines the hypothesized number of cointegration relations, i.e. the rank of the matrix (r). The number of cointegration relations is smaller than 1, i.e., "None", following Trace test's null hypothesis. If the statistic is higher than the critical value, the null hypothesis is rejected. The Eigenvalue test examines the null that the number of cointegration relations (r) is " 0 ". The critical values for both tests are derived from the Trace and Maximum Eigenvalue of the stochastic matrix. '***', '**' and '*' indicate that the corresponding null hypothesis can be rejected at the $1 \%, 5 \%$, and $10 \%$ significance level, respectively.

Table 4: Johansen tests results assuming no trend in the data

\section{No intercept in CE}

Null Eigenvalue Trace statistic 5\% critical value

hypothesis

$\begin{array}{llll}\text { None } & 0.128 & 71.147^{* * *} & 40.175 \\ \text { At most1 } & 0.055 & 28.610^{* *} & 24.276 \\ \text { At most 2 } & 0.022 & 11.119 & 12.321\end{array}$

At most 2

0.014

4.130

Max. Eigenvalue statistic

\begin{tabular}{lllc} 
& & \multicolumn{2}{c}{ Max. Eigenvalue statistic } \\
\hline 0 & 0.128 & $42.537 * * *$ & 24.159 \\
1 & 0.055 & 17.491 & 17.797 \\
2 & 0.022 & 6.769 & 11.225
\end{tabular}

$\begin{array}{llll}2 & 0.022 & 6.769 & 11.225 \\ 0.014 & 4.350 & 4.130\end{array}$

Note: See Table 3.

\begin{tabular}{lclc}
\hline $\begin{array}{l}\text { Constant in CE } \\
\text { Null hypothesis }\end{array}$ & Eigenvalue & Trace statistic & $5 \%$ critical value \\
& & & 54.079 \\
None & 0.131 & $77.359^{* * *}$ & 35.192 \\
At most1 & 0.056 & $33.841^{*}$ & 20.262 \\
At most 2 & 0.029 & 15.811 & 9.165 \\
At most 3 & 0.022 & 6.765 & \\
& & \multicolumn{2}{c}{ Max. Eigenvalue statistic } \\
\hline 0 & 0.131 & $43.519^{* * *}$ & 28.588 \\
1 & 0.056 & 18.030 & 22.299 \\
2 & 0.029 & 9.045 & 15.892 \\
3 & 0.022 & 6.766 & 9.165
\end{tabular}

\section{Constant in CE}

$0.022 \quad 6.766$ 
If we assume no trend in the data, we must reject no cointegration at least at the one percent significance level (see Table 4). Allowing for a constant in the error correction, the null hypotheses of both tests are rejected at the $10 \%$ significance level, indicating that $r$ is at most equal to 1. If we estimate without a constant, we cannot reject a rank of one at the five percent level (Table 4 left column).

We conclude that the cointegration analysis is dependent on the assumptions we have made for the underlying dataset. However, we have evidence for at least one long-run relation in the system and present time series evidence on this relation in the next steps. If there is more than one long-run relation, we might also find regime switches in the data. The remainder of this section explores different systems with one long-run relation - and thus one equilibrium.

\subsection{Evidence on the interest rate system: The interest rate bonus over 25 years}

If we restrict the vector of CHF and EUR rates to $[1 ;-1]$ in the corresponding VECM, which is meaningful since we are especially interested in the CHF/EUR relation, the long-run relation can be depicted as follows ( $\mathrm{t}$-statistics in brackets):

$$
\begin{array}{cclc}
\mathrm{CHF}=\mathrm{EUR} & -0.205 \mathrm{USD} & -0.094 \mathrm{GBP} & -0.359 \\
& {[2.256]} & {[1.492]} & {[1.719]}
\end{array}
$$

Testing the null hypothesis of exogeneity (Chi-square $(2)=2.498$ ) of GBP, we drop the insignificant GBP time series from the long-term relation and get:

$$
\begin{array}{lll}
\mathrm{CHF}=\mathrm{EUR} & -0.329 \mathrm{USD} & -0.375 \\
& {[6.956]} & {[1.746]}
\end{array}
$$

Further restricting the long-run relation by excluding USD rates leads to the rejection of the null hypothesis (Chi-square $(3)=27.216)$. The USD significance in $(5)$ indicates that we can exclude GBP rates but not the USD rates from the system. Since we are interested in the pairwise interest rate bonus we estimate the long run relation between the Swiss franc and the Euro in the bivariate case. The corresponding model does not allow for the rejection of the null hypothesis with Chi-square (1) equal to $1.344^{3}$ :

$\mathrm{CHF}=\mathrm{EUR}-1.26$

$$
\text { [4.744] }
$$

\footnotetext{
${ }^{3} \mathrm{~A}$ VAR on CHF and EUR offers a lag length of 3 that allows for $\mathrm{CIR}=1$ after a Johansen test at the $5 \%$ significance levels.
} 
The interest rate premium for the Swiss franc is thus about 1.25 percentage points, which is slightly larger than previous estimates, e.g., the bonus of 1.1 percentage points that Kirchgässner (2003) observed for the period from January 1981 to February 2003. The same test strategy as above (with a Chi-square $(1)=0.8068$ ) shows that the interest rate anomaly is even larger for the Swiss franc against the USD by about 2 percentage points. The bonus is 20 basis points lower compared to Mollick and Assefa (2013), who did however not include the post-crisis period when rates plunged to the zero lower bound (ZLB).

$\mathrm{CHF}=\mathrm{USD}-1.998$

We refrain from further interpretation of the bivariate Swiss interest rate bonus estimates and instead estimate a model that includes EUR, GBP and USD.

\subsection{Model specification of a 25 year CHF, EUR, USD, GBP interest rate system:}

Further specifications are required before we perform additional tests on the long-run relation. This is achieved by causality tests between the variables in the model using VAR Granger causality and block exogeneity Wald tests. The tests provide information about the direction of causality among variables. Causality can be uni-directional, bi-directional or neutral as depicted in Table 5. Since the variables are cointegrated we use a lag-augmented version of the test.

Table 5 VAR Granger causality and block exogeneity Wald test, 1989m1 -2015m2

\begin{tabular}{|c|c|c|c|c|c|c|c|}
\hline \multirow[t]{2}{*}{ Variable $x_{i t}$} & \multicolumn{3}{|c|}{ Dependent Variable CHF } & \multirow[t]{2}{*}{ Variable $x_{i t}$} & \multicolumn{3}{|c|}{ Dependent Variable EUR } \\
\hline & $\mathbf{F}\left(\mathrm{x}_{\mathrm{it}}->\mathrm{CHF}\right)$ & Causality & Block Exogeneity & & $\mathbf{F}\left(\mathbf{x}_{\text {it }}->\right.$ EUR $)$ & Causality & Block Exogeneity \\
\hline EUR & $16.157 * * *$ & $\begin{array}{c}\text { bi }(\text { EUR<- } \\
>\text { CHF })\end{array}$ & & CHF & $32.698 * * *$ & $\begin{array}{c}\text { bi }(\mathrm{CHF}<- \\
>\text { EUR })\end{array}$ & \\
\hline USD & $13.862 * * *$ & uni (USD->CHF) & $48.190 * * *$ & USD & $17.254 * * *$ & $\begin{array}{l}\text { uni (USD- } \\
\text { >EUR) }\end{array}$ & $112.905 * * *$ \\
\hline \multirow[t]{3}{*}{ GBP } & $10.032 * *$ & bi $(\mathrm{GBP}<->\mathrm{CHF})$ & & GBP & $23.843 * * *$ & uni (GBP->EUR) & \\
\hline & \multicolumn{3}{|c|}{ Dependent Variable USD } & & \multicolumn{3}{|c|}{ Dependent Variable GBP } \\
\hline & $\mathbf{F}\left(\mathbf{x}_{\mathrm{it}}->\mathrm{USD}\right)$ & Causality & Block Exogeneity & & $\mathbf{F}\left(\mathbf{x}_{\mathrm{it}}->\mathbf{G B P}\right)$ & Causality & Block Exogeneity \\
\hline CHF & 6.728 & uni (USD->CHF) & & CHF & $10.373 * *$ & bi $(\mathrm{GBP}<->\mathrm{CHF})$ & \\
\hline EUR & 4.956 & $\begin{array}{c}\text { uni (USD- } \\
\text { >EUR) }\end{array}$ & 13.158 & EUR & 2.448 & uni (GBP->EUR) & $37.986 * * *$ \\
\hline GBP & 0.938 & uni (USD->GBP) & & USD & $17.434 * * *$ & uni (USD->GBP) & \\
\hline
\end{tabular}

We find evidence that EUR, USD and GBP rates are Granger causal for CHF rates at the 1 percent significance level. Block exogeneity of EUR, USD and GBP rates is rejected at the same level. The corresponding evidence for EUR interest rates leads us to conclude that CHF and EUR rates are jointly influenced by any rate in the system, whereas causality between EUR and CHF rates is bi-directional. This shows the large degree of integration of the two currency 
areas. However, GBP interest rates are not influenced by EUR rates. The USD rate is not influenced by any rate in the system. In addition, block exogeneity cannot be rejected for USD rates. This result leads to the conclusion that the USD rates have an influence on all European currencies but that the opposite does not hold.

In the next step we proceed with the VECM initially estimated for equation (4) under particular consideration of the causality and exogeneity test results to further examine the relations between the time series. We assume one cointegration vector in the system, as indicated by the Johansen test, which describes the long-run relation in a VECM as follows:

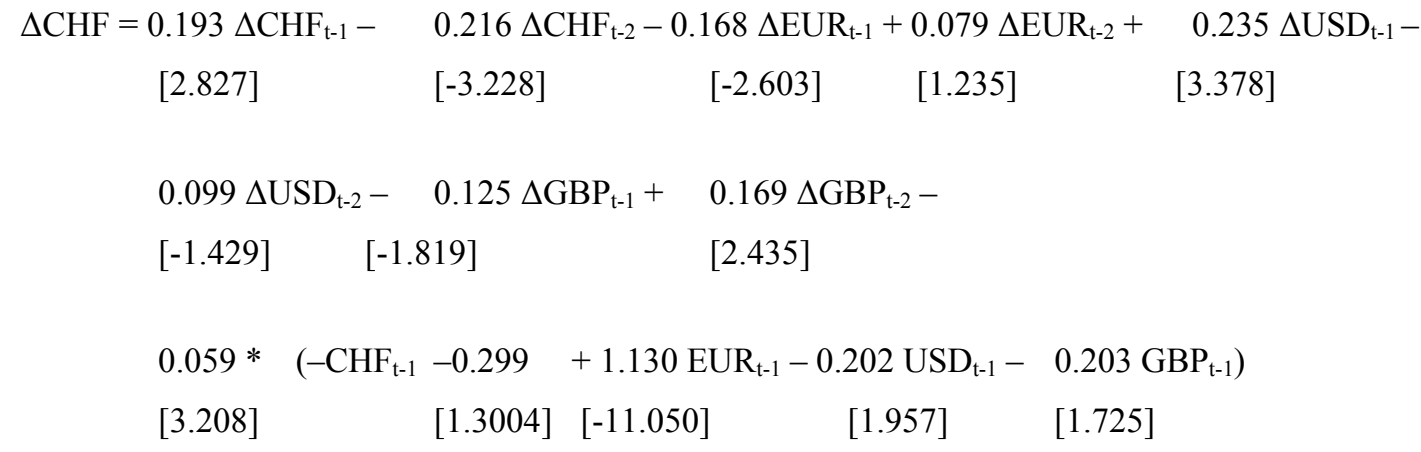




$$
\begin{aligned}
& \Delta \mathrm{GBP}=0.190 \Delta \mathrm{CHF}_{\mathrm{t}-1}-0.006 \Delta \mathrm{CHF}_{\mathrm{t}-2}-0.067 \Delta \mathrm{EUR}_{\mathrm{t}-1}+\quad 0.032 \Delta \mathrm{EUR}_{\mathrm{t}-2}+\quad 0.229 \Delta \mathrm{USD}_{\mathrm{t}-1}- \\
& {[2.833] \quad[-0.086] \quad[-1.058] \quad[0.513] \quad[3.365]} \\
& 0.086 \Delta \mathrm{USD}_{\mathrm{t}-2}+\quad 0.243 \Delta \mathrm{GBP}_{\mathrm{t}-1}-\quad 0.033 \Delta \mathrm{GBP}_{\mathrm{t}-2}- \\
& {[-1.252] \quad[3.607] \quad[-0.480]} \\
& 0.020 * \quad\left(-\mathrm{CHF}_{\mathrm{t}-1}-0.299+1.130 \mathrm{EUR}_{\mathrm{t}-1}-0.202 \mathrm{USD}_{\mathrm{t}-1}-0.203 \mathrm{GBP}_{\mathrm{t}-1}\right) \\
& {[1.084] \quad[1.300] \quad[-11.050] \quad[1.957] \quad[1.725]}
\end{aligned}
$$

Adj. $R^{2}=0.164 \quad$ S.E. $=0.264$

The results of the VECM (8a)-(8b) confirm the Granger causality tests of Table 5: The USD rates have a significant influence on CHF and EUR rates. GBP rates are not significant in the long-run relationship (8a)-(8b). The long run relationship is not significant for USD and GBP rates $(8 c)-(8 d)$.

This evidence allows for imposing further restrictions on the VECM. First, we drop GBP from the long-run relation of the system. Second, we test whether USD and GBP are weakly exogenous, i.e., we test whether the long-run relationship is not significant in the corresponding VECM. Conjointly testing these two restrictions, the Chi-square statistic does not allow for rejecting this null hypothesis with a value of 6.00. Adjusted R-squared values are slightly lower (see 9), but signs and significances of coefficients remain about identical when comparing (8a) with (9) (although we have restricted the system to weak exogeneity of USD and GBP rates).

$$
\begin{aligned}
& \Delta \mathrm{CHF}=0.212 \Delta \mathrm{CHF}_{\mathrm{t}-1}-0.205 \Delta \mathrm{CHF}_{\mathrm{t}-2}-0.169 \Delta \mathrm{EUR}_{\mathrm{t}-1}+\quad 0.088 \Delta \mathrm{EUR}_{\mathrm{t}-2}+\quad 0.227 \Delta \mathrm{USD}_{\mathrm{t}-1}- \\
& {[3.091] \quad[-3.022] \quad[-2.585] \quad[1.353] \quad[3.248]} \\
& 0.109 \Delta \mathrm{USD}_{\mathrm{t}-2}-\quad 0.122 \Delta \mathrm{GBP}_{\mathrm{t}-1}+\quad 0.177 \Delta \mathrm{GBP}_{\mathrm{t}-2}- \\
& {[-1.568] \quad[-1.763] \quad[2.563]} \\
& 0.047 *\left(-\mathrm{CHF}_{\mathrm{t}-1}-\quad 0.459+0.938 \mathrm{EUR}_{\mathrm{t}-1}-0.245 \mathrm{USD}_{\mathrm{t}-1}\right) \\
& {[2.424] \quad[2.203] \quad[-17.025] \quad[3.623]}
\end{aligned}
$$

Adj. $\mathrm{R}^{2}=0.113 \quad$ S.E. $=0.272$

The results of the VECM confirm previous evidence: the finding that US monetary policy may have an instantaneous impact on European interest rates but not vice versa is in line with the pre-crisis evidence provided by Brüggemann and Lütkepohl (2005).

Finally, we test whether the interest rate bonus has disappeared after the financial crisis. We observe the full sample of EUR and CHF and compare the interest rate bonus as calculated in 
(6) before and after the Lehman event (Table 6, second row). Accordingly, we test whether the SNB decision to set a EUR/CHF floor has reduced the interest rate bonus (Table 6, third row). We therefore analyze three systems: the first system starts after the Lehman event and ends with the most recent observation in February 2015 (Table 6 second row). The second system starts after the Lehman event and ends before the SNB decision to impose a EUR/CHF floor (2008m10 2011m08); the third system starts after the SNB event and ends before the floor was discontinued.

Table 6 Interest rate bonus CHF EUR for selected periods

\begin{tabular}{ccccc|cccc}
\hline \multirow{2}{*}{ Event } & \multicolumn{3}{c}{ Premium before event occurred } & \multicolumn{5}{c}{ Premium after event occurred } \\
& Start & End & Premium & $\begin{array}{c}\text { Chi- } \\
\text { square }\end{array}$ & Start & End & Premium & Chi-square \\
\hline Lehman & $1989 \mathrm{~m} 01$ & $2008 \mathrm{~m} 09$ & $1.953^{* * *}$ & 0.549 & $2008 \mathrm{~m} 10$ & $2015 \mathrm{~m} 02$ & $\left(0.386^{* * *}\right)$ & $62.075^{* * *}$ \\
& & & {$[17.178]$} & & & & {$[3.984]$} & \\
SNB (floor) & $2008 \mathrm{~m} 10$ & $2011 \mathrm{~m} 08$ & $\left(0.614^{* * *}\right)$ & $35.797^{* * *}$ & $2011 \mathrm{~m} 10$ & $2014 \mathrm{~m} 12$ & $\left(0.186^{* * *}\right)$ & $4.493^{* *}$ \\
& & & {$[7.155]$} & & & & {$[2.703]$} & \\
\hline
\end{tabular}

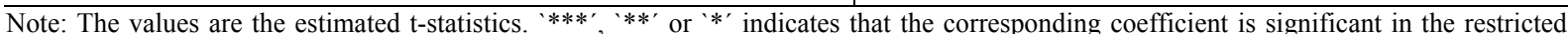
Vector Error Correction at the 1, 5, or 10 percent level. Results in brackets represent statistical artefacts: They are significant in the model, but the model as a whole does not withstand closer scrutiny and is therefore not statistically significant (See Chi-square values). Lag selection according to the VAR presented above.

The results of the three systems show the demise of the interest rate bonus after the Lehman event in September 2008. The bonus is reduced to insignificant levels in several steps. This evidence supports Kugler and Weder (2009), who expected a shrinking bonus over the course of the crisis. We conclude that by setting up a EUR/CHF floor, the SNB could effectively reduce the bonus to insignificant and lower levels if we analyze this phenomenon with monthly data.

\subsection{Robustness checks}

Since monthly data results might induce a small " $\mathrm{t}$ "-problem due to the limited observations of the periods after the Lehman and the SNB events of 2011 and 2015, we double check the results with daily data following the same test procedure as in equations (2)-(9). We include GBP and USD rates to have more explanatory power in the model but restrict their influence on the longterm relation between $\mathrm{CHF}$ and EUR rates as shown above.

Table 7 Interest rate bonus CHF EUR: Robustness check with daily data

\begin{tabular}{ccccc}
\hline Event & \multicolumn{3}{c}{ Premium after event occurred } \\
& Start & End & $\begin{array}{c}\text { Premium } \\
\text { [t-value] }\end{array}$ & Chi-Square \\
\hline Lehman -> SNB & $2008 \mathrm{~m} 09 \mathrm{~d} 15$ & $2011 \mathrm{~m} 09 \mathrm{~d} 05$ & $0.685^{* * *}$ & 6.405 \\
& & & {$[9.155]$} & \\
SNB -> today & $2011 \mathrm{~m} 09 \mathrm{~d} 06$ & $2015 \mathrm{~m} 04 \mathrm{~d} 15$ & $0.189^{* * *}$ & $26.425^{* * *}$ \\
& & & {$[2.830]$} & \\
\hline
\end{tabular}

Note: See notes Table 6. 
Table 7 depicts the robustness checks with daily data of the following two models: the first model starts after the Lehman event on September 15, 2008 and ends at the day before the SNB event on September 5, 2011. The second model starts on September 6, 2011 when the SNB announced the establishment of the exchange rate floor and ends on April $15^{\text {th }} 2015$, the most recent date in our dataset.

We obtain a significant interest rate bonus after the Lehman event until the day before the SNB's decision to install an exchange rate floor on September 6, 2011. This is evidence in support of a persistent interest rate bonus during the first years of the crisis. The second row of table 7 depicts the results of the second model. It reveals that the bonus has been compressed below 20 basis points and that it is not significant on April 15, 2015. This evidence supports our conclusion in 5.3: The interest rate bonus has disappeared during the period of the exchange rate floor. However it did so only after the SNB installed a floor regime. We conclude that the interest bonus has been reduced to insignificant levels ever since. Hence, we can affirmatively argue that the UIRP holds again. In addition, we find that the demise of the interest rate bonus happened during the period of the SNB floor regime, presumably during the period between 2011 and 2014. Table 8 depicts the evidence in support of the reversal of the interest rate anomaly during Q4.2013-Q3.2014. Note that we cannot reject model SNB+24m, while we do reject model $\mathrm{SNB}+36 \mathrm{~m}$ at least on the five percent level.

Table 8 Interest rate bonus after during the floor regime of the SNB

\begin{tabular}{|c|c|c|c|c|}
\hline \multirow[t]{2}{*}{ Event } & \multicolumn{3}{|c|}{ Premium after event occurred } & \multirow[b]{2}{*}{ Chi-Square } \\
\hline & Start & End & $\begin{array}{l}\text { Premium } \\
\text { [t-value] }\end{array}$ & \\
\hline Lehman -> SNB & $2008 \mathrm{~m} 09 \mathrm{~d} 15$ & $2011 \mathrm{~m} 09 \mathrm{~d} 05$ & $\begin{array}{l}0.685 * * * \\
{[9.155]}\end{array}$ & 6.405 \\
\hline $\mathrm{SNB}+12 \mathrm{~m}$ & $2011 \mathrm{~m} 09 \mathrm{~d} 06$ & $2012 \mathrm{~m} 09 \mathrm{~d} 06$ & $\begin{array}{l}0.512 * * * \\
{[4.978]}\end{array}$ & 3.911 \\
\hline $\mathrm{SNB}+24 \mathrm{~m}$ & $2011 \mathrm{~m} 09 \mathrm{~d} 06$ & $2013 \mathrm{~m} 09 \mathrm{~d} 05$ & $\begin{array}{l}0.269 * * * \\
{[4.212]}\end{array}$ & 5.390 \\
\hline $\mathrm{SNB}+36 \mathrm{~m}$ & $2011 \mathrm{~m} 09 \mathrm{~d} 06$ & 2014m09d5 & $\begin{array}{l}(0.236 * * *) \\
{[4.960]}\end{array}$ & $10.806^{* *}$ \\
\hline $\mathrm{SNB}+40 \mathrm{~m}$ & $2011 \mathrm{~m} 09 \mathrm{~d} 06$ & $2015 \mathrm{~m} 01 \mathrm{~d} 14$ & $\begin{array}{l}(0.214 * * *) \\
{[3.985]}\end{array}$ & $13.804 * * *$ \\
\hline
\end{tabular}

We refrain from further interpreting the size of the bonus and discontinue the linear analysis since we find more than one cointegration relationship in the models $\mathrm{SNB}+12, \mathrm{SNB}+24 \mathrm{~m}$, $\mathrm{SNB}+36 \mathrm{~m}$ and $\mathrm{SNB}+40 \mathrm{~m}$. This might indicate multiple long-run relationships that indicate regime switches. In addition, this evidence supports Hofmann and Suter's work (2010) who 
expected a "latent" bonus in the interest rate systems of CHF and EUR Libor rates after the crisis: this "latent" bonus might be a hidden Markov regime. Thus, we will further analyze the time series with non-linear regime switching techniques and conclude that we have, at least, evidence for the demise of the interest rates bonus and a switch in the long-term interest rate regimes.

\section{Non-linear evidence: Switching Regression}

Since we have evidence that the interest rate bonus was reduced during the period that coincides with the SNB floor regime and since we have evidence that the bonus is not statistically significant (by April 2015), we refrain from further linear modeling and test whether the interest rate system is subject to regime switching. Regime changes occur after large-scale events, crises or force majeure. Any of the latter is associated with sharp changes in financial data that might better be estimated with non-linear models.

\subsection{Regime and switching specification with regime-specific error variances}

We model heteroscedasticity in the regime analysis for the following reasons: first, heteroscedasticity can be expected in macroeconomic data that exhibits high volatility during intermittent periods (Hamilton 1996, Kim et al. 2015). Second, we find evidence for nonconstant variance in section 5.1: non-stationarity of the variables (see Table 2) crisis point at this feature. Even if we find evidence for stationarity and find zero means (e.g., of the interest rate differential in Table 1), the marginal variance might be subject to changes over time and exhibit heteroscedasticity - even if the mean is constant. Third and against the evidence from section 5.2 (see Table 3 and 4), we find a long-run relation of the corresponding interest rates. The series might therefore be at least conditionally heteroscedastic (Krolzig 1997). This is the case if the unconditional variance is constant in the long-run, but is non-constant in the short run. Since we have at least one long-run relation, we must have some short run time-varying variance. Thus, evidence for cointegration can be associated with conditional heteroscedasticity. Taken together, we cannot reject heteroscedasticity in the data.

For these reasons, we allow for heteroscedasticity across regimes and estimate regime-specific error variances as described below. We specify the estimation as follows: First, the probability regressor is dependent on a constant term. Second, the initial regime probabilities are set to the ergodic (steady states) values implied by the Markov transition matrix (Kim and Nelson 1999). The values are then treated as functions of the parameters that determine the transition matrix. 
Third, standard errors and covariance are estimated using numeric Hessian. Fourth, the random search is set to 50 starting values and 20 iteration refinements.

\subsection{Switching Regression Results}

We explore regime switching in the CHF time series and report model specifications and estimates of the log standard deviations in the low and high interest rate periods in Table 9:

Table 9: Regime switching in the monthly CHF 3m series 1989m1-2015m2

\begin{tabular}{|c|c|c|c|}
\hline $\begin{array}{l}\text { Dependent Variable } \\
\text { Variable }\end{array}$ & Coefficient & Std. Error & Probability \\
\hline & & \multicolumn{2}{|c|}{ Regime 1} \\
\hline Log Sigma & -6.202 & 0.109 & 0.000 \\
\hline & & \multicolumn{2}{|c|}{ Regime 2} \\
\hline Log Sigma & -3.127 & 0.048 & 0.000 \\
\hline & & \multicolumn{2}{|c|}{ Transition Matrix Parameter } \\
\hline P11-C & 3.636 & 0.660 & 0.000 \\
\hline $\mathrm{P} 21-\mathrm{C}$ & -4.843 & 0.727 & 0.000 \\
\hline Mean dependent var & 0.026 & S.D.dependent var & 0.027 \\
\hline S.E. of regression & 0.037 & Sum squared resid & 0.437 \\
\hline Akaike info criterion & -4.982 & Log likelihood & 786.144 \\
\hline
\end{tabular}

\begin{tabular}{|c|c|c|}
\hline \multicolumn{3}{|c|}{$\begin{array}{l}\text { Constant transition probabilities: } \\
\mathrm{P}(\mathrm{i}, \mathrm{k})=\mathrm{P}(\mathrm{s}(\mathrm{t})=\mathrm{k} \mid \mathrm{s}(\mathrm{t}-1)=\mathrm{i}) \\
(\text { row }=\mathrm{i} / \text { column }=\mathrm{j})\end{array}$} \\
\hline & 1 & 2 \\
\hline 1 & 0.974 & 0.026 \\
\hline 2 & 0.008 & 0.992 \\
\hline \multicolumn{3}{|c|}{ Constant expected durations: } \\
\hline & 1 & 2 \\
\hline & 38.922 & 127.791 \\
\hline
\end{tabular}

Implied standard deviations are 0.20 percentage points for the low interest rate regime (Regime 1) and 4.38 percentage points for the high interest rate volatility regime (Regime 2). Note that the coefficients differ from zero in all of the tests. There is state dependence in the transition probabilities with a high probability to remain in a regime. The expected durations in either of the regimes differ with approximately 3.25 years in the low interest rate regime and 10.5 years in the high interest rate regime. One-step ahead predictions are reported in the Appendix (see Appendix A.1). Note that switches occur at points when the SNB sharply reduced interest rates to the lower bound.

As we are most interested in the excess return of CHF over EUR short-term interest rates, we test for regime switching in the series. We know that the series is $\mathrm{I}(0)$ (see Table 1 ), but the variance can still be time variant. Therefore, we test with regime specific error variances. Since we know that the bonus disappears over time (section 5), we expect at least one regime switch. If we thus cannot reject a regime switch, we have significant evidence for a "hidden" bonus regime, since the system can fall back into the "old" regime. The results with monthly data are reported in Table 10: 
Table 10 : Regime Switching in $\Delta \mathrm{e}$ CHF/EUR monthly 1989m1-2015m2

\begin{tabular}{|c|c|c|c|}
\hline \multicolumn{4}{|c|}{ Dependent Variable: $\Delta e$ CHF/EUR } \\
\hline Variable & Coefficient & Std. Error & Probability \\
\hline & & \multicolumn{2}{|c|}{ Regime 1} \\
\hline Log Sigma & -5.660 & 0.292 & 0.000 \\
\hline & & \multicolumn{2}{|c|}{ Regime 2} \\
\hline Log Sigma & -3.866 & 0.046 & 0.00 \\
\hline \multicolumn{4}{|c|}{ Transition Matrix Parameter } \\
\hline $\mathrm{P} 11-\mathrm{C}$ & 3.357 & 1.070 & 0.002 \\
\hline $\mathrm{P} 21-\mathrm{C}$ & -4.967 & 0.723 & 0.000 \\
\hline Mean dependent var & -0.017 & S.D.dependent var & 0.009 \\
\hline S.E. of regression & 0.020 & Sum squared resid & 0.117 \\
\hline Akaike info criterion & -5.340 & Log likelihood & 842.319 \\
\hline
\end{tabular}

Constant transition probabilities: $\mathrm{P}(\mathrm{i}, \mathrm{k})=\mathrm{P}(\mathrm{s}(\mathrm{t})=\mathrm{k} \mid \mathrm{s}(\mathrm{t}-1)=\mathrm{i})$ (row $=\mathrm{i} /$ column $=\mathrm{j}$ )

\begin{tabular}{c|cc} 
& 1 & 2 \\
\hline 1 & 0.967 & 0.034 \\
2 & 0.007 & 0.993
\end{tabular}

Constant expected durations:

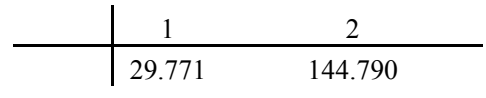

Graph 1 One-step Ahead Predicted Regime Probabilities:

$P(S(t)=1)$

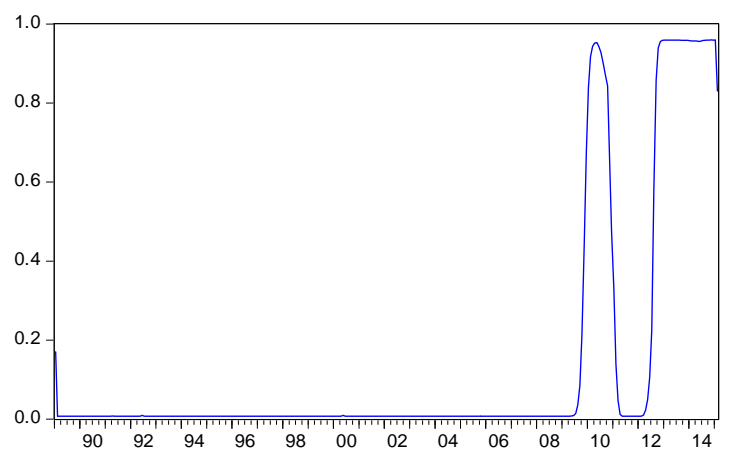

$P(S(t)=2)$

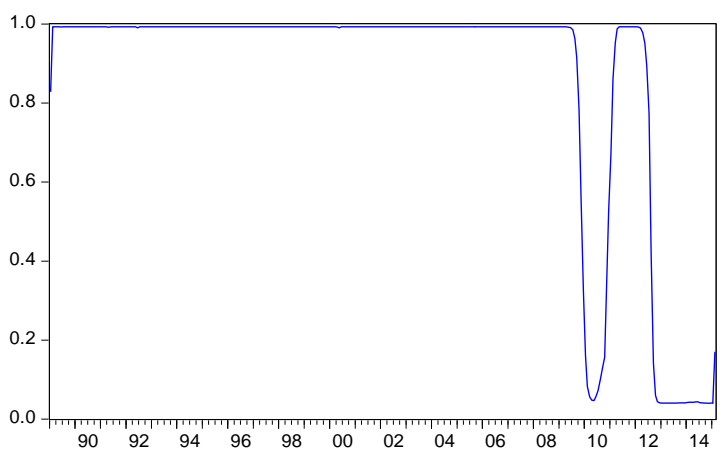

Implied standard deviations are 0.35 percentage points for the low interest rate difference regime (Regime 1) and 2.09 percentage points for the high interest rate difference regime (Regime 2). Note that the coefficients differ from zero in all of the tests. Transition probabilities point at a long duration of remaining in the initial regime. The expected duration of remaining in the "bonus" regime is five times longer than vice versa. The expected duration of the "bonus" period is 12 years. One-step ahead predictions show that the regimes have switched twice in the wake of the crisis. The "bonus" regime was interrupted between 2009 and 2010 and finally disappeared in 2012 (see Graph 1). Note that we observe another switch in January 2015. This switching coincides with the end of the floor of the SNB. To double-check this observation, we repeat the analysis with daily data (see Appendix A.2). The results confirm the estimates from the analysis with monthly data. The probabilities and durations are increased in favor of staying in the "bonus" regime. The implied volatility of the bonus regime is similar compared to the results with monthly data. The implied volatility of regime 1 is lower by 7 basis points. The standard errors of the coefficients are significantly reduced. The one-step ahead predicted regime probabilities indicate the same regime switches as with monthly data. 
Since we are interested in the reasons why the "bonus" regime disappeared, we re-estimate with data reaching back to September 5, 2011, the day before the SNB announced the introduction of the EUR/CHF floor. The results (Table 11) show an implied standard deviation of 0.16 for the low (Regime 1) and 1.04 for the "bonus" regime (Regime 2). We have evidence for a compressed bonus after the SNB event. While the expected duration of regime 1 was 3 years in August 2014, the duration of remaining in regime 1 has been reduced to 1.25 years - or 5 quarters. Note that the regime switch occurs during the third quarter of 2012 (see Graph 2).

The above illustrated Markov regime switching models lack an important feature: they do not interact with a parameter that models the SNB's use of unconventional monetary policy instruments during the crisis. In the next step we model time varying transition and regime heteroscedastic regime switching of the interest rate difference $\mathrm{CHF} / \mathrm{EUR}$ returns conditional on SNB foreign currency investments (in EUR assets). We believe that those can explain the demise of the interest rate anomaly.

Table 11: Regime Switching in series $\Delta \mathrm{e}$ CHF/EUR daily

\begin{tabular}{|c|c|c|c|}
\hline \multicolumn{4}{|c|}{ Dependent Variable: $\Delta e \mathrm{CHF} / \mathrm{EUR}$ daily September $5^{\text {th }} 2011-$ April $15^{\text {th }} 2015$} \\
\hline $\mathrm{V}$ riable & Co fficient & Std. Error & Probabil ty \\
\hline & & \multicolumn{2}{|c|}{ Regime 1} \\
\hline \multirow[t]{2}{*}{ Log Sigma } & -6.430 & & 0.000 \\
\hline & & \multicolumn{2}{|c|}{ Regime $2^{0.000}$} \\
\hline \multirow[t]{2}{*}{ Log Sigma } & -4.605 & 0.043 & 0.000 \\
\hline & & \multicolumn{2}{|c|}{ Transition Matrix Parameter } \\
\hline P11-C & 6.103 & 0.789 & 0.000 \\
\hline $\mathrm{P} 21-\mathrm{C}$ & -6.270 & 1.167 & 0.000 \\
\hline Mean dependent var & -0.004 & S.D.dependent var & 0.004 \\
\hline S.E. of regression & 0.006 & Sum squared resid & 0.029 \\
\hline Akaike info criterion & -8.872 & Log likelihood & 4054.139 \\
\hline
\end{tabular}

\begin{tabular}{|c|c|c|}
\hline \multicolumn{3}{|c|}{$\begin{array}{l}\text { Constant transition probabilities: } \\
\mathrm{P}(\mathrm{i}, \mathrm{k})=\mathrm{P}(\mathrm{s}(\mathrm{t})=\mathrm{k} \mid \mathrm{s}(\mathrm{t}-1)=\mathrm{i}) \\
(\text { row }=\mathrm{i} / \text { column }=\mathrm{j})\end{array}$} \\
\hline & 1 & 2 \\
\hline 1 & 0.997 & 0.002 \\
\hline 2 & 0.002 & 0.998 \\
\hline \multicolumn{3}{|c|}{ Constant expected durations: } \\
\hline & 1 & 2 \\
\hline & 448.149 & 529.333 \\
\hline
\end{tabular}

Graph 2 One-step Ahead Predicted Regime Probabilities:

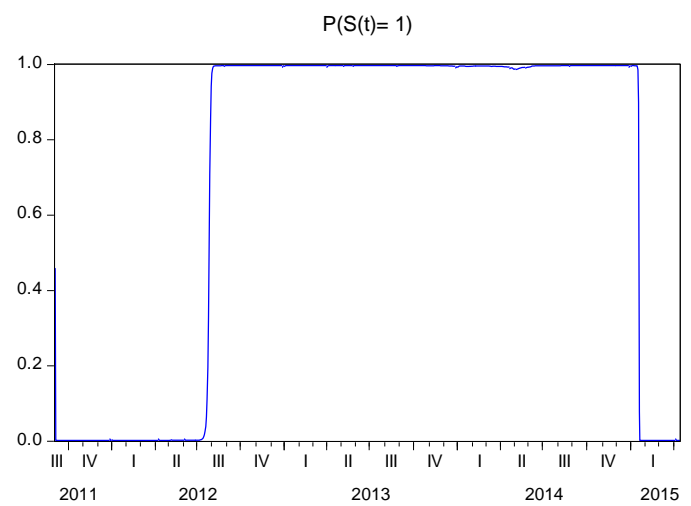

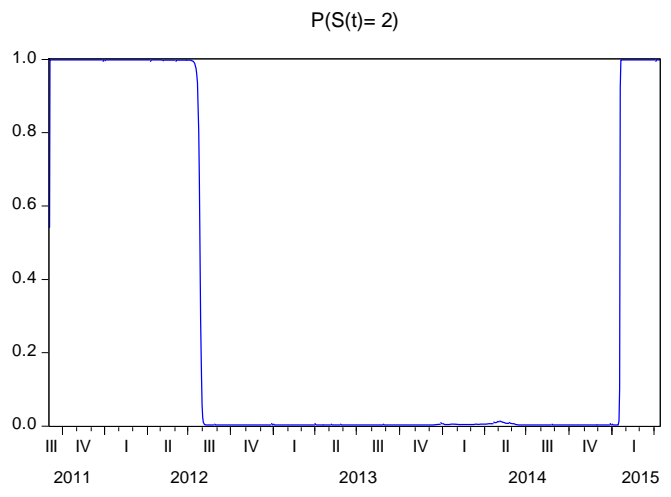


In order to provide an overview, we have depicted monthly time series data illustrating the increase in foreign currency investments on the SNB balance sheet (see Appendix A.3). ${ }^{4}$ Note that the increase in foreign currency investments was part of the containment strategy to counter any further appreciation of the CHF (e.g. SNB 2011). In addition, we have depicted the share of EUR assets in total foreign currency investments in the Appendix (see Appendix A.4). Note the peak during phases of high volatility. Local maxima can be found in the wake of the Lehman event and before the SNB event.

We want to test whether the currency investments of the SNB can operate as a probability regressor in Markov regime switching of the EUR/CHF interest rate differential. We therefore test whether the containment action of the SNB in the wake of the Lehman event and the announcement of the establishment of the EUR/CHF floor had a significant impact on the demise of the bonus. If we cannot reject the possibility of an influence of the SNB currency investments on the demise of the interest rate bonus, we have evidence that the interest rate parity is forced to hold by force majeure.

The estimates are reported in Table 12: The results show an implied standard deviation of 1.60 for the "bonus" regime (regime 1) that runs from 1999 to 2009 and 0.30 for the low regime (regime 2) that starts at the end of the second quarter of 2012. The interim period shows switches between these two regimes. Note the peak marking the one month switch from regime 1 to regime 2 in August 2011. This peak coincides with strong increases of SNB purchases of EUR assets. The bonus regime finally disappears in 2012. We therefore have evidence that the demise of the bonus is conditional upon the SNB's appreciation containment actions.

Graph 3 depicts the one-step ahead predicted regime probabilities. Note, again, the impact of the SNB's increase of EUR currency on the interest rate difference that is switching to the low volatility regime in August 2011. This is most relevant to our study for the following reasons: First, it shows that the SNB's action to invest into EUR assets contributed to the reversal of the interest rate anomaly. Second, the final switching into the low regime took place almost a year after the SNB announced the EUR/CHF floor. Thus, the announcement of the SNB did not directly reverse the interest rate bonus. It came about after the SNB made one large intervention

\footnotetext{
${ }^{4}$ See SNB website for series A1: http://www.snb.ch/en/iabout/stat/statpub/statmon/stats/statmon/statmon_A1
} 
in EUR assets during the peak of the Euro crisis. It is however not possible to explore this issue further since we do not have access to these confidential data. Ever since, the SNB has not had to increase their relative positions in EUR assets in accordance with the balance sheet. On the contrary, the SNB could reduce the relative exposure to EUR denominated assets to pre-crisis levels by January 2015 (SNB 2015), such that the SNB was successful to frame market expectations and the UIRP held again.

Table 12: Regime switching in $\triangle \mathrm{e} C H F / E U R$ in interaction with SNB foreign currency investments

\begin{tabular}{|c|c|c|c|c|c|c|}
\hline \multicolumn{4}{|c|}{ Dependent Variable: $\Delta e$ CHF/EUR; ASS100 monthly 1999-2014 } & \multirow{3}{*}{\multicolumn{3}{|c|}{$\begin{array}{l}\text { Time varying transition probabilities: } \\
\mathrm{P}(\mathrm{i}, \mathrm{k})=\mathrm{P}(\mathrm{s}(\mathrm{t})=\mathrm{k} \mid \mathrm{s}(\mathrm{t}-1)=\mathrm{i}) \\
(\text { row }=\mathrm{i} / \text { column }=\mathrm{j})\end{array}$}} \\
\hline Variable & Coefficient & Std. Error & Probability & & & \\
\hline \multirow{3}{*}{ Log Sigma } & \multirow{3}{*}{-4.132} & \multicolumn{2}{|c|}{ Regime 1} & & & \\
\hline & & 0.059 & \multirow{2}{*}{$2^{0.000}$} & & & \\
\hline & & Res & & Mean & 1 & 2 \\
\hline \multirow[t]{2}{*}{ Log Sigma } & \multirow[t]{2}{*}{-5.804} & 0.122 & 0.000 & 1 & 0.984 & 0.015 \\
\hline & & \multicolumn{2}{|c|}{ Transition Matrix Parameter } & 2 & 0.019 & 0.981 \\
\hline P11-C & 6.303 & 1.589 & 0.000 & & & \\
\hline P11-ASS100 & -15.338 & 5.063 & 0.003 & & & \\
\hline $\mathrm{P} 21-\mathrm{C}$ & -5.396 & 1.744 & 0.002 & Std.Dev & 1 & 2 \\
\hline P21-ASS 100 & 13.573 & 6.822 & 0.047 & 1 & 0.096 & 0.096 \\
\hline \multirow{6}{*}{$\begin{array}{l}\text { Mean dependent var } \\
\text { S.E. of regression } \\
\text { Akaike info criterion }\end{array}$} & \multirow{6}{*}{$\begin{array}{c}-0.013 \\
0.015 \\
-5.949\end{array}$} & \multirow{6}{*}{$\begin{array}{l}\text { S.D.dependent var } \\
\text { Sum squared resid } \\
\text { Log likelihood }\end{array}$} & \multirow{6}{*}{$\begin{array}{c}0.006 \\
0.039 \\
556.258\end{array}$} & 2 & 0.097 & 0.097 \\
\hline & & & & & & \\
\hline & & & & \multicolumn{3}{|c|}{ Time varying expected durations: } \\
\hline & & & & & 1 & 2 \\
\hline & & & & Mean & 614.873 & 239.323 \\
\hline & & & & Std.Dev & 549.864 & 176.244 \\
\hline
\end{tabular}

Graph 3 One-step Ahead Predicted Regime Probabilities

$P(S(t)=2)$
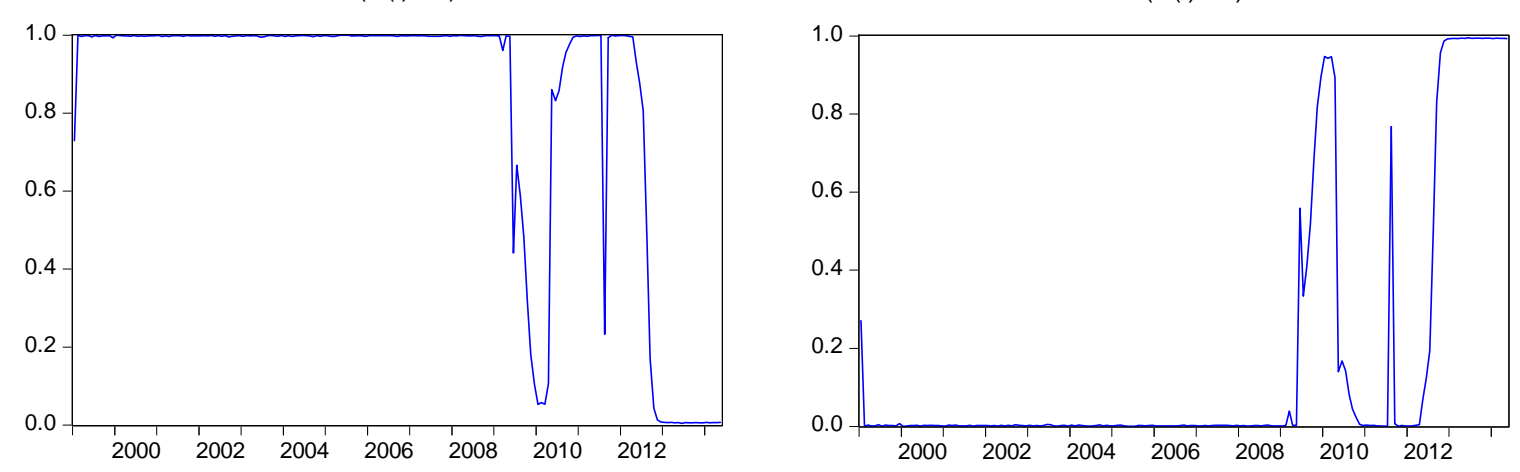

The most interesting remaining question is whether the bonus reappears after SNB discontinued its EUR/CHF floor. Since we had evidence for another regime switch in the dependent variable, we interact it with foreign currency investments with most recent data. Results are reported in Table 13.

Graph 4 depicts the results of the dependent variable in interaction with monthly differences of foreign currency investments of the SNB. Note that the likelihood of remaining in regime 1 has 
been reduced significantly. In addition, note that the coefficient of remaining in regime 1 by interaction with foreign investments is different from zero on the ten percent level only. Furthermore, time varying expected durations could not be estimated for regime 1. Taken together, this constitutes evidence for a de-compression of the interest rate differential and thus for the re-emergence of an interest rate bonus. We therefore find evidence in support of Hoffmann and Suter (2010), who expected a reappearance of the Swiss interest rate anomaly. We refrain from forecasting a revival of the violation of the UIRP, but we have significant evidence for a "latent", i.e., hidden bonus regime of CHF rates by February 2015.

Table 13: Regime switching in $\triangle \mathrm{e}$ CHF/EUR conditional on SNB foreign currency investments

\begin{tabular}{|c|c|c|c|}
\hline \multicolumn{4}{|c|}{ Dependent Variable: $\Delta e$ CHF/EUR; monthly 1999-2015 } \\
\hline Variable & Coefficient & Std. Error & Probability \\
\hline \multirow{3}{*}{ Log Sigma } & & \multicolumn{2}{|c|}{ Regime 1} \\
\hline & -5.832 & 0.137 & 0.000 \\
\hline & & \multicolumn{2}{|c|}{ Regime 2} \\
\hline \multirow[t]{2}{*}{ Log Sigma } & -4.133 & 0.059 & 0.000 \\
\hline & & \multicolumn{2}{|c|}{ Transition Matrix Parameter } \\
\hline $\mathrm{P} 11-\mathrm{C}$ & 3.673 & 1.354 & 0.007 \\
\hline P11-ASS100 & 115.816 & 68.265 & 0.090 \\
\hline $\mathrm{P} 21-\mathrm{C}$ & -5.529 & 1.367 & 0.000 \\
\hline P21-ASS100 & 13.207 & 4.948 & 0.008 \\
\hline Mean dependent var & -0.012 & S.D.dependent var & 0.007 \\
\hline S.E. of regression & 0.014 & Sum squared resid & 0.038 \\
\hline Akaike info criterion & -6.053 & Log likelihood & 593.159 \\
\hline
\end{tabular}

Graph 4 One-step Ahead Predicted Regime Probabilities

\begin{tabular}{|c|c|c|}
\hline \multicolumn{3}{|c|}{$\begin{array}{l}\text { Time varying transition probabilities } \\
\mathrm{P}(\mathrm{i}, \mathrm{k})=\mathrm{P}(\mathrm{s}(\mathrm{t})=\mathrm{k} \mid \mathrm{s}(\mathrm{t}-1)=\mathrm{i}) \\
(\text { row }=\mathrm{i} / \text { column }=\mathrm{j})\end{array}$} \\
\hline Mean & 1 & 2 \\
\hline 1 & 0.869 & 0.132 \\
\hline 2 & 0.001 & 0.983 \\
\hline Std.Dev & 1 & 2 \\
\hline 1 & 0.263 & 0.263 \\
\hline 2 & 0.088 & 0.088 \\
\hline \multicolumn{3}{|c|}{ Time varying expected durations: } \\
\hline & 1 & 2 \\
\hline Mean & NA & 268.736 \\
\hline Std.Dev & NA & 188.231 \\
\hline
\end{tabular}

$\mathrm{P}(\mathrm{S}(\mathrm{t})=2)$

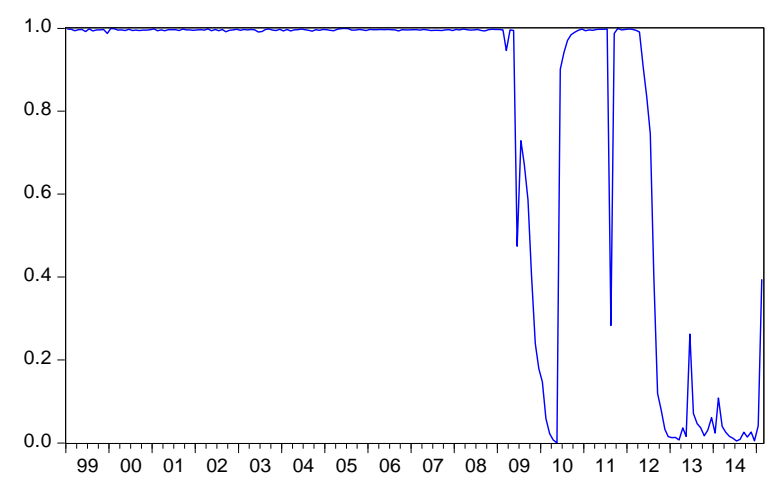

Since we do not have access to daily (or even monthly) data on the EUR denominated foreign currency investments of the SNB, we strongly recommend interacting these time series with the interest rate differentials to further explore the regime switching process of the interest rate anomaly as a robustness check. We have supplemented a model in the appendix (A.5), with quarterly data. Evidence is in support of our previous findings. Due to the limited timeliness of 
data and a corresponding low variance over time of the interaction variable, we refrain from interpreting the results.

To sum up, we have found evidence for non-linear regime switching of the interest rate bonus that explains the demise of the interest rate anomaly. At last, we find evidence for the reappearance of the "hidden" bonus regime in February 2015.

\section{Conclusion}

In this paper, we have investigated whether the Swiss interest rate anomaly persists after the Great Recession and, in particular, after the Swiss National Bank imposed an exchange rate floor to the Euro. According to our results, the interest rate bonus of CHF denominated assets has been reduced during the crisis. However, only the SNB's appreciation containment actions have finally compressed it to insignificant levels. To sum up, we find evidence for the demise of the interest rate anomaly such that the UIRP finally holds again.

While earlier studies show the re-appearance of the interest rate bonus (e.g., Kirchgässner 2003) and predict its demise in the wake of the financial crisis (Kugler and Weder 2009), we find a "significant bonus period" way into the crisis and show that it has disappeared to insignificant levels over the last years. With this evidence we support the "safe haven" explanation of the interest rate anomaly and show that the UIRP does not hold during this first period. On the other hand, we find a "hidden" bonus regime during the financial crisis and support Hoffmann and Suter (2010) who expect a re-appearance of the interest rate bonus.

We offer new insights on the interest rate anomaly: first, we find evidence that the UIRP holds in the regime of compressed interest rates. We have shown that market actors still expected a bonus. These expectations were reversed by the SNB's action. Second and directly related to the latter, we present evidence for a non-linear interest rate bonus and find regime switches during the financial crisis. This finding supports the argument that the interest bonus has vanished but might return after the suspension of the exchange rate floor in January 2015. This is why we conclude that we find a "latent" safe haven characteristic of the CHF. Third, we have found that the SNB's increase in EUR denominated assets had an impact on the reversal of the interest rate anomaly. It is noteworthy that the SNB's announcement of the introduction of a floor was not accompanied with strong increases of EUR assets in the balance sheet. To sum up, the SNB's announcement to target an exchange rate floor was credible enough to frame market expectations. Therefore, we have evidence that the signal to defend the exchange rate 
floor is an effective and credible tool. Thus, the SNB had been very successful to form market expectations such that the UIRP held during the floor regime. However, estimations with most recent data point at a de-compression of rates and another regime switch after the SNB has discontinued the exchange rate floor. The first impressions are that there might be a revival of the Swiss interest rate anomaly after all.

\section{Acknowledgements}

We would like to thank two anonymous referees, Bernd Fitzenberger, Jan-Egbert Sturm and Jan Schnellenbach for their valuable comments.

\section{References}

Alvarez, F., Atkeson, A. and Kehoe, P. 2007. If Exchange Rates are Random Walks, Then Almost Everything We Say about Monetary Policy Is Wrong. American Economic Review, Papers and Proceedings 97, 339-345.

Baltensperger, E. 2012. Der Schweizer Franken - eine Erfolgsgeschichte. Neue Zürcher Zeitung, Zürich.

BIS, 2013. 83rd BIS Annual Report 2012/2013, Basel, Switzerland.

Brüggemann, R. and Lütkepohl, H. 2005. Uncovered Interest Parity and the Expectation Hypothesis of the Term Structure: Empirical Results for the U.S. and Europe. Applied Economics Quarterly 51, 143-154.

Cheung, Y.-W., Chinn, M. and Pascual, A. 2005. Empirical Exchange Rate Models of the Nineties: Are Any Fit to Survive? Journal of International Money and Finance 27, 1150-1175.

Cunat, A., 2003. The Causes and Consequences of Low Interest Rate in Switzerland. Background paper for the Annual Report of the Kommission für Konjunkturfragen.

Dreger, C. and Schumacher, C. 2003. Are Real Interest Rates Cointegrated? Further Evidence Based on Panel Econometric Methods. Schweizerische Zeitschrift für Volkswirtschaft und Statistik 139, 4153.

Engel, C., Mark, N.C. and West, K.D. 2008. Exchange Rate Models are Not as Bad as You Think. In D. Acemoglu, K. Rogoff and M. Woodford (eds.), NBER Macroeconomics Annual 2007, Volume 22. Chicago: University of Chicago Press, 381-441.

Engel, C. and West, K.D. 2005. Exchange Rates and Fundamentals. Journal of Political Economy 11, 485-517.

Frenkel, J.A. and Levich, R.M. 1975. Covered Interest Arbitrage: Unexploited profits? Journal of Political Economy 83(2), 325-338.

Frenkel, J.A. and Levich, R.M. 1977. Transaction costs and interest arbitrage? Journal of Political Economy 85(6), 1209-1226.

Grisse, C. and Nitschka, T. 2015. On financial risk and the safe haven characteristics of Swiss franc exchange rates. Journal of Empirical Finance 32, 153-164. 
Hamilton, J.D. 1996. Specification testing in Markov-switching time-series models. Journal of Econometrics 70, 127-157.

Hoffmann, M. and Suter, R. 2010. The Swiss Franc Exchange Rate and Deviations from Uncovered Interest Parity: Global vs Domestic Factors. Swiss Journal of Economics and Statistics 146(1), 349372 .

Keynes, J.M. 1923. A Tract on Monetary Reform. London: Macmillan.

Kim, C.J. and Nelson, C. R. 1999. State-Space Models with Regime Switching. Cambridge, Massachusetts: MIT Press.

Kim, C.J., Morley, J. and Piger, J. 2015. Introduction to "Special Issue on the empirical Analysis of Business Cycles, Financial Markets and Inflation: Essays in Honor of Charles Nelson". Macroeconomic Dynamics 19(4), 723-727.

Kirchgässner, G. 2003. Die Wiederkehr des Zinsbonus - Neue empirische Ergebnisse zum Einfluss der europäischen und der amerikanischen auf die schweizerischen Euromarktzinsen. Aussenwirtschaft $59,249-274$.

Kirchgässner, G. and Wolters, J. 1987. U.S.- European Interest Rate Linkage: A Time Series Analysis for West Germany, Switzerland and the United States. The Review of Economics and Statistics 69(4), 675-684.

Kirchgässner, G. and Wolters, J. 1991. Die Abhängigkeit der schweizerischen von der europäischen und amerikanischen Zinsentwicklung - Empirische Ergebnisse für die achtziger Jahre. Schweizerische Zeitschrift für Volkswirtschaft und Statistik 127(3), 631-646.

Kirchgässner, G. and Wolters, J. 1993. Does the DM Dominate the Euro Market? An Empirical Investigation. The Review of Economics and Statistics 69(4), 675-684.

Kirchgässner, G. and Wolters, J. 1995. Interest Rate Linkages in Europe Bond Market? An Empirical Investigation. Empirical Economics 20(3), 435-454.

Krishnakumar, J. and Neto, D. 2012. Testing Uncovered Interest Parity and Term Structure Using a Three-Regime Threshold Unit Root VECM: An Application of the Swiss Isle of Interest Rates. Oxford Bulletin of Economics and Statistics 74, 180-202.

Krolzig, H-M. 1997. Markov-Switching Vector Autoregressions: Modelling, Statistical Inference, and Application to Business Cycle Analysis. Berlin: Springer.

Kugler, P. and Weder, B. 2002. The Puzzle of the Swiss Interest Island: Stylized Facts and a New Interpretation. Aussenwirtschaft 57, 49-63.

Kugler, P. and Weder, B. 2004. International Portfolio Holdings and Swiss franc Asset Returns. Schweizerische Zeitschrift für Volkswirtschaft und Statistik 140, 301-325.

Kugler, P. and Weder, B. 2005. Why are Returns on Swiss franc Asset so Low? Applied Economics Quarterly 51(3), 231-246.

Kugler, P. and Weder, B. 2009. The Demise of the Swiss Interest Rate Puzzle. SNB-IMF Conference on Exchange Rates.

Lütkepohl, H. 2005. New Introduction to Multiple Time Series Analysis. Berlin: Springer.

Meese, R.A. and Rogoff K. 1983. Empirical Exchange Rate Models of the Seventies: Do They Fit out of Sample? Journal of International Economics 14, 3-24. 
Mishkin, F.S., 1984. Are Real Interest Rates Equal Across Countries? An Empirical Investigation of International Parity Conditions. Journal of Finance 39, 1345-1357.

Mollick, A. and Assefa, T.A. 2013. Carry-trades on the Yen and the Swiss franc: Are they different? Journal of Economics and Finance 37(3), 402-423.

Ricardo, D. 1811. Reply to Mr. Bosanquet's Practical Observations on the Report of the Bullion Committee, Davison, London.

Rogoff, K.S. and Stavrakeva, V. 2008. The Continuing Puzzle of Short Horizon Exchange Rate Forecasting. NBER Working Paper 14071.

Rossi, B. 2013. Exchange Rate Predictability. Journal of Economic Literature 51, 1063-1119.

SNB. 2007. $100^{\text {th }}$ Annual Report, Swiss National Bank, Zurich.

Studer, J. and Jordan T. 2015. Preface. SNB $2014107^{\text {th }}$ Annual Report, Swiss National Bank, Zurich, 57.

Taylor, M.P. 1987. Covered Interest Parity: A High-Frequency, High-Quality Data Study. Economica $54,429-438$.

Taylor, M.P. 1989. Covered Interest Arbitrage and Market Turbulence, Economic Journal 99, 376-391.

Walras, L. 1874. Elements of Pure Economics. New York: Kelly. 


\section{Appendix}

A.1: Graph: CHF Regime Probabilities 1989-2014

$P(S(t)=1)$

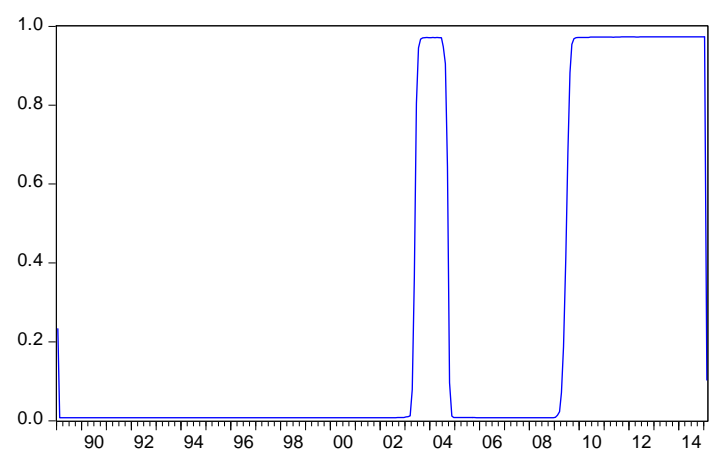

$P(S(t)=2)$

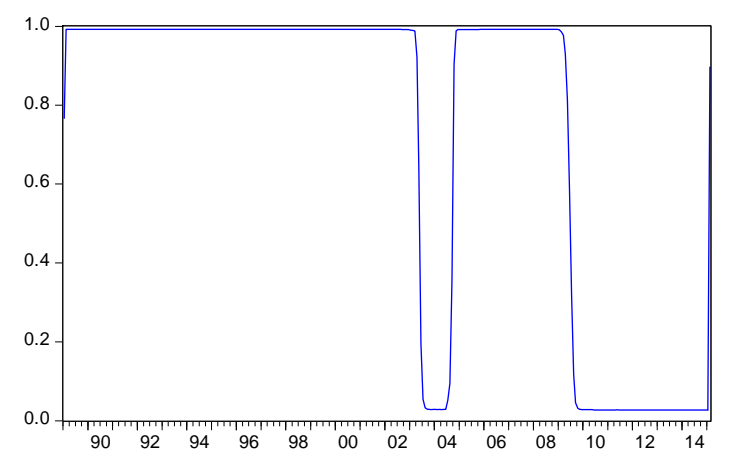

A.2: Table and Graph A2 Regime Probabilities Daily Difference $\Delta$ e CHF/EUR daily 1989-2014

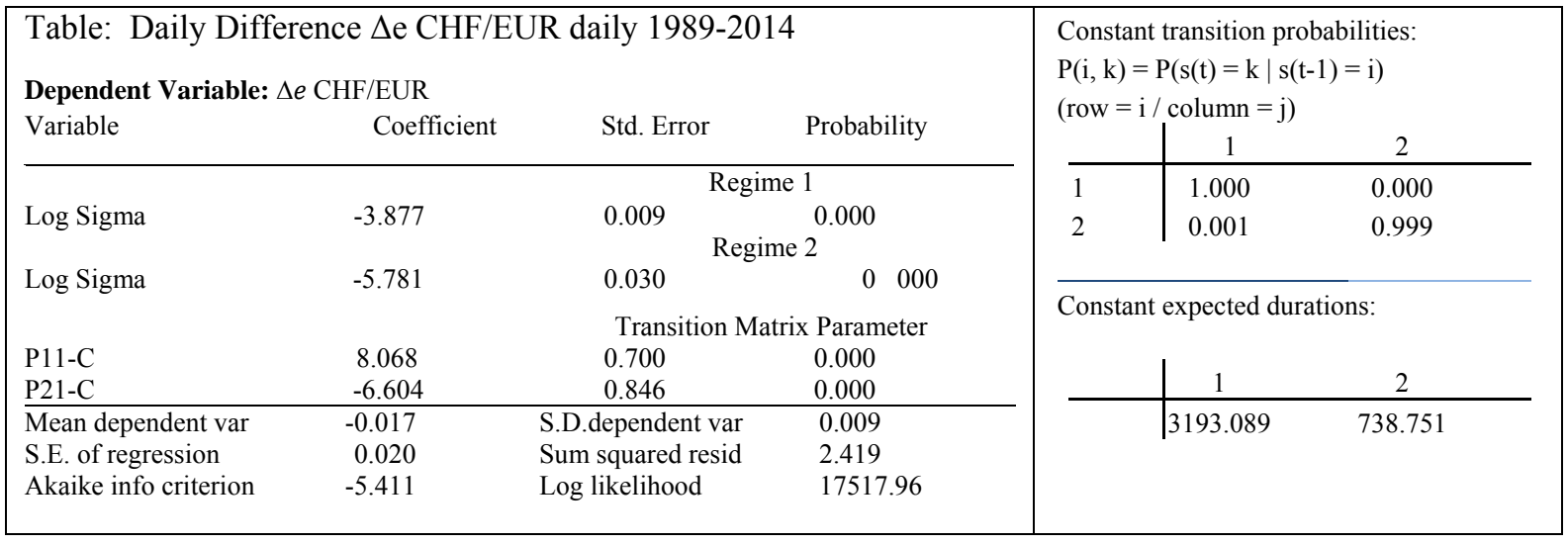

$P(S(t)=1)$

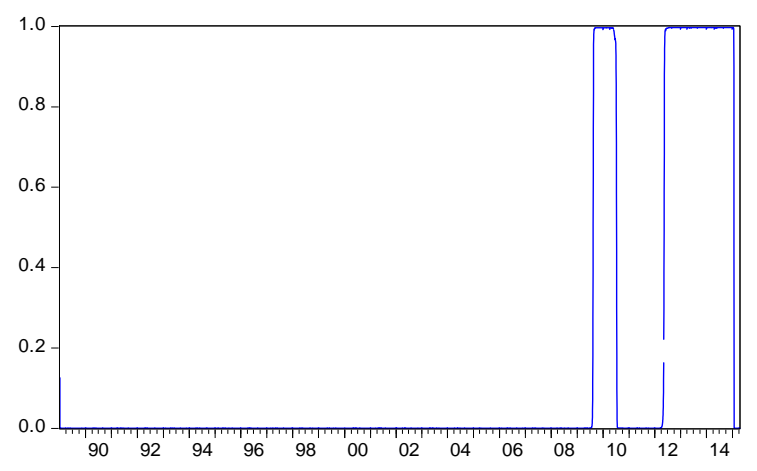

$P(S(t)=2)$

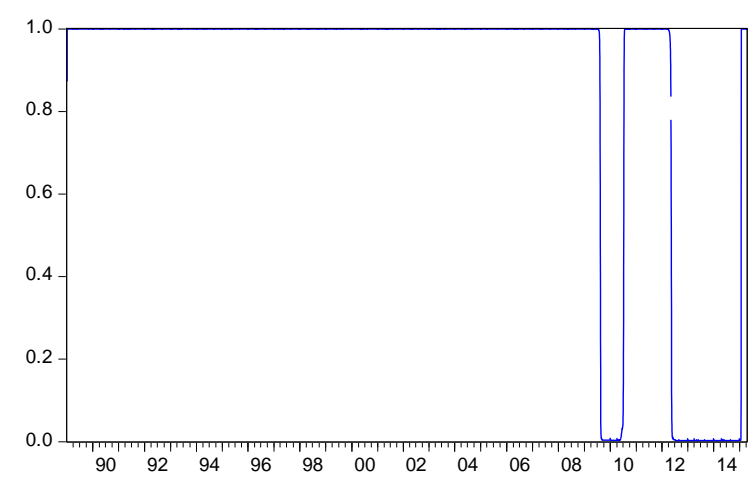


A.3: Graph A3 SNB balance sheet items in share of total assets (Dec 1996 - Feb 2015)

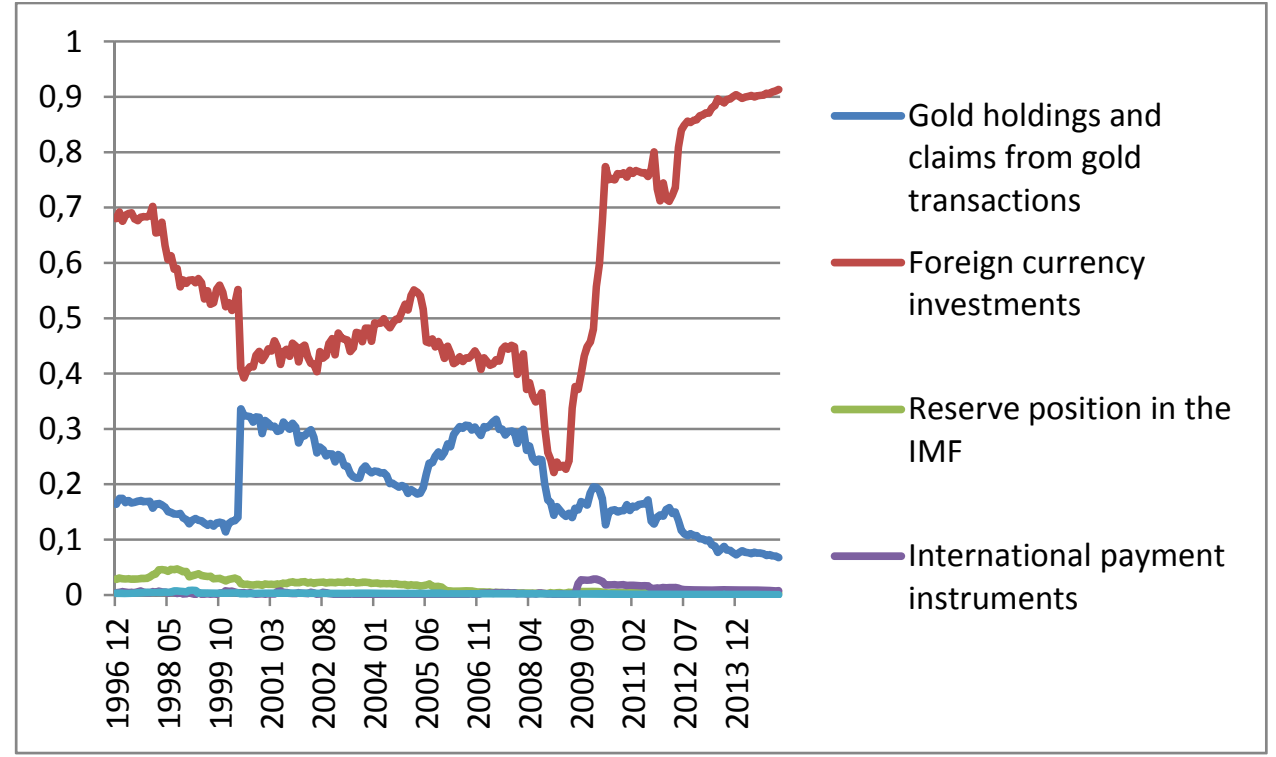

\section{EUR currency investments of the SNB SNB A3 2}

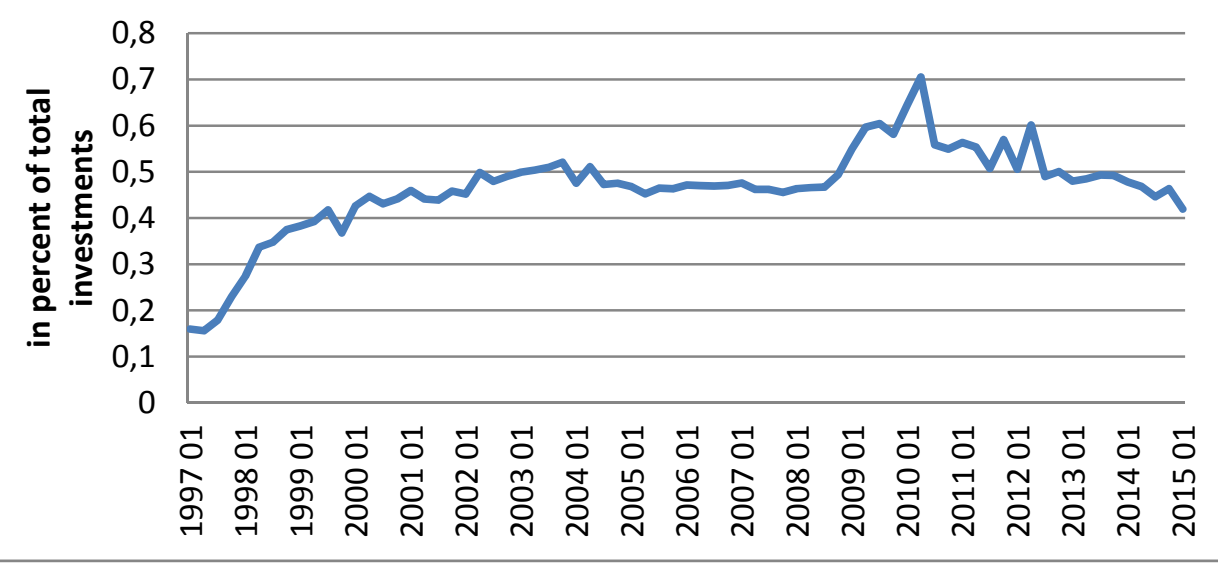


A.5: Graph A5 Regime Probabilities Difference $\Delta$ e CHF/EUR daily 1999-2015 in interaction with SNB currency investments with quarterly data (A3_2)

$P(S(t)=1)$

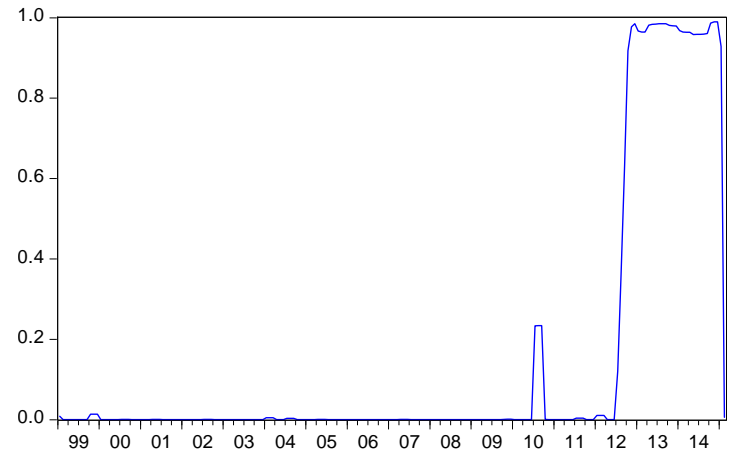

$\mathrm{P}(\mathrm{S}(\mathrm{t})=2)$

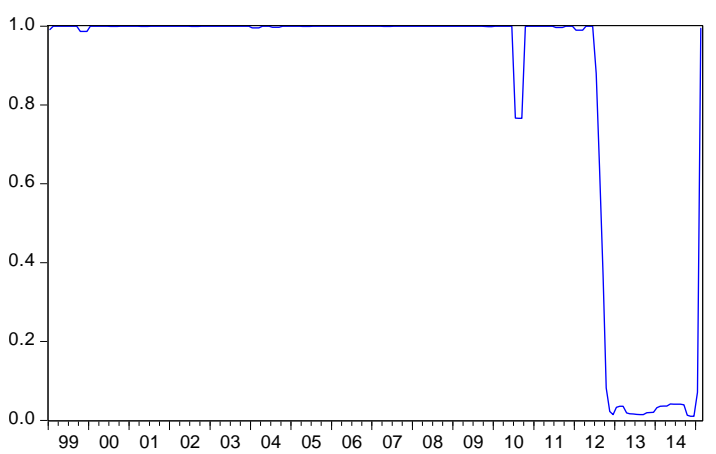

